\title{
Fast Marching Method Aplication for Forward Modelling of Seismic Wave Propagation
}

\author{
Aplikasi Fast Marching Method untuk Pemodelan Ke-depan Propagasi Gelombang Seismik
}

\author{
Srigutomo $\mathrm{W}^{*}$ dan Muslim G. H. \\ Fisika Bumi dan Sistem Kompleks, Fakultas Matematika dan Ilmu Pengetahuan Alam, Institut Teknologi Bandung, \\ Jl. Ganesa 10 Bandung, Indonesia, 40132 \\ *Email: wahyu@fi.itb.ac.id
}

Submit: 2018-04-24; Revised: 2018-11-15 ; Accepted: 2018-12-25

\begin{abstract}
One of the classical problem in seismology is to determine time travel and ray path of seismic wave between two points at a given heterogeneous media. This problem is expressed by eikonal equation and can be seen as a propagation of a wavefront and interface evolution. One of methods to solve this problem is Fast Marching Method abbreviated as FMM. This method is used to produce entropy-satisfying viscosity solution of eikonal equation. FMM combines viscosity solution of Hamilton-Jacobi equation and Huygen's Principle that centered on min-heap data structure to determine the minimum value at every loop. In this study, FMM is applied to determine time travel and raypath of seismic wave. FMM also is used to determine the location of wave source using simple algorithm. From our forward modeling schemes, it is found that FMM is an accurate, robust, and efficient method to simulate seismic wave propagation. For further study, FMM also can be used to be a part of passive seismic inverse scheme to locate hypocenter location.
\end{abstract}

Keywords: eikonal equation, Fast Marching Method, seismic wave propagation

Abstrak: Salah satu masalah klasik pada bidang seismologi adalah penentuan waktu tempuh dan lintasan dari gelombang seismik antara dua titik pada suatu medium heterogen di bawah permukaan. Persamaan yang mewakili masalah tersebut adalah persamaan eikonal. Masalah ini dapat dipandang sebagai perambatan muka gelombang dan evolusi bidang batas. Salah satu metode untuk menyelesaikan persoalan tersebut adalah Fast Marching Method disingkat FMM. Metode ini digunakan untuk menghasilkan solusi viskositas yang memenuhi kondisi entropi terhadap persamaan eikonal. FMM menggabungkan solusi viskositas dari persamaan Hamilton-Jacobi dan prinsip Huygen dengan berpusat pada struktur data min-heap untuk menentukan nilai minimum pada setiap loop. Pada studi ini, FMM diaplikasikan untuk menentukan waktu tempuh dan lintasan gelombang seismik pada berbagai variasi medium. FMM juga digunakan untuk menentukan lokasi sumber gelombang seismik menggunakan algoritma sederhana. Dari berbagai skema pemodelan yang dilakukan didapat kesimpulan bahwa FMM merupakan metode yang akurat, robust dan efesien untuk memodelkan penjalaran gelombang seismik. Sebagai pertimbangan untuk studi lanjutan, FMM pun dapat dimanfaatkan dalam inversi metode seismik pasif untuk penentuan lokasi hiposenter.

Kata kunci: persamaan eikonal, Fast Marching Method, penjalaran gelombang

\section{PENDAHULUAN}

Salah satu masalah klasik pada bidang seismologi adalah penentuan waktu tempuh dan lintasan dari gelombang seismik antara dua titik pada suatu medium heterogen di bawah permukaan. Metode analitik tidak adapat digunakan memecahkan masalah karena kompleksnya persebaran kecepatan di bawah permukaan. Salah satu metode numerik yang digunakan pada permasalahan ini adalah shooting method atau bending method. Shooting method merupakan metode untuk menyelesaikan masalah di atas dari perspektif persoalan syarat awal.

Sedangkan bending method menyelesaikan masalah di atas dari perspektif persoalan syarat batas dengan mengubah lintasan secara iteratif hingga memenuhi prinsip Fermat (Rawlinson, 2008). Kekurangan dari shooting method dan bending method adalah persoalan robustness (kekuatan) dan faktor kecepatan komputasi (Rawlinson, 2005). Untuk model dengan variasi kecepatan yang kecil, kedua metode ini dapat gagal mencapai konvergensi. Keduanya akan memakan waktu yang sangat lama pada kasus sumber dan detektor (geofon) yang sangat banyak. Sehingga dibutuhkan suatu metode lain yang robust dan efisien.

Pertanyaan yang menarik yang akan dicoba untuk dijawab dalam studi ini adalah bagaimana metode numerik yang cukup robust dan efisien untuk menentukan penjalaran gelombang seismik pada suatu model kecepatan heterogen di bawah permukaan. Dalam makalah ini pertama dibahas secara ringkas teori gelombang seismik beserta algoritma dasar evolusi muka-gelombang disertai algoritma dasar dari Fast Marching Method, ray tracing, pembiasan dan pemantulan gelombang, dan penentuan lokasi gempa. Dipaparkan hasil simulasi seismik menggunakan Fast Marching Method beserta informasi akurasi dan efisiensinya dan aplikasi Fast Marching Method pada seismologi. 


\section{DASAR TEORI}

Metode seismik memanfaatkan propagasi gelombang di bawah permukaan Bumi. Propagasi gelombang sangat bergantung pada sifat elastik dari batuan. Ukuran dan bentuk dari sebuah benda dapat diubah dengan memberikan gaya terhadap permukaan luar dari benda tersebut. Gaya luar ini dilawan oleh gaya internal yang mempertahankan perubahan ukuran dan bentuk. Hasilnya, benda tersebut cenderung kembali ke keadaan awal ketika gaya luar dihilangkan. Sifat untuk mempertahankan bentuk atau ukuran dan kembali ke keadaan awal ketika gaya luar dihilangkan disebut elastisitas. Sebuah benda yang elastik sempurna adalah benda yang kembali ke keadaan semula secara sempurna. Banyak bahan, termasuk batuan, yang dapat dianggap elastik sempurna jika deformasi yang terjadi kecil, seperti pada survei seismik. Teori elastisitas menghubungkan gaya eksternal terhadap perubahan ukuran dan bentuk yang terjadi. Hubungan tersebut dapat diekspresikan dengan mudah dengan menggunakan konsep tegangan dan regangan.

\subsection{Persamaan Gelombang Elastik}

Persamaan gelombang seismik dapat diturunkan dengan menggunakan hukum Newton. Terdapat dua buah gaya yang bekerja pada material yang bergetar, yaitu gaya tubuh dan gaya permukaan:

$$
\sum F=F_{\text {body }}+F_{\text {surface }}=m \mathbf{a}
$$

atau dalam bentuk diferensialnya,

$$
\rho g+\nabla \cdot \sigma=\rho \frac{\partial^{2} \mathbf{u}}{\partial t^{2}}
$$

dengan $\mathbf{F}$ adalah gaya, $m$ adalah massa material, a adalah percepatan gerak, $\rho$ adalah rapat massa material, $\mathbf{g}$ merupakan percepatan gravitasi, $\sigma$ adalah tensor tegangan, $\mathbf{u}$ berupa vektor perpindahan suatu titik pada material, dan $t$ merupakan waktu. Jika gelombang jauh dari sumber dengan frekuensi yang cukup besar, maka gaya tubuh dapat diabaikan, sehingga

$$
\nabla . \sigma=\rho \frac{\partial^{2} \mathbf{u}}{\partial t^{2}}
$$

Pada medium isotropik, hubungan tegangan dan regangan dipenuhi oleh persamaan

$$
\sigma_{i j}=\lambda \delta_{i j} \theta+2 \mu e_{i j}
$$

sehingga apabila secara konsisten diturunkan akan didapatkan hubungan

$$
\nabla \cdot \sigma=\nabla \lambda(\nabla \cdot u)+\lambda \nabla(\nabla \cdot u)+\mu \nabla^{2} u+\mu \nabla(\nabla \cdot u)+2 e . \nabla \mu
$$

di mana $\lambda$ serta $\mu$ adalah konstanta-konstanta Lame, e berupa tensor regangan sedangkan $\theta=e_{x x}+e_{y y}+e_{z z}$. Dengan menggunakan aturan triple product yaitu $\nabla x \nabla x u=$ $\nabla(\nabla . u)-\nabla^{2} u$, maka

$\rho \ddot{u}=\nabla . \sigma=\nabla \lambda(\nabla . u)+(\lambda+2 \mu) \nabla(\nabla . u)-\mu \nabla \times \nabla \times u+2 e . \nabla \mu$.
Pada kasus frekuensi tinggi $\nabla \lambda$ dan $\nabla \mu$ dapat diabaikan [8]. Sehingga,

$$
\rho \ddot{u}=(\lambda+2 \mu) \nabla(\nabla \cdot u)-\mu \nabla \times \nabla \times u .
$$

Dengan menggunakan teorema Helmholtz

$$
u=\nabla \Phi+\nabla \times \Psi
$$

dan mensubstitusikannya ke persamaan dinamika, maka

$\rho \frac{\partial^{2}}{\partial t^{2}}(\nabla \Phi+\nabla \times \Psi)=(\lambda+2 \mu) \nabla\left(\nabla^{2} \Phi\right)-\mu \nabla \times\left(\nabla(\nabla . \Psi)-\nabla^{2} \Psi\right)$

dengan menggunakan transformasi Gauge $\nabla \cdot \Psi=0$, maka akan didapatkan

$$
\nabla\left[(\lambda+2 \mu) \nabla^{2} \Phi-\rho \frac{\partial^{2} \Phi}{\partial t^{2}}\right]=-\nabla \times\left[\mu \nabla^{2} \Psi-\rho \frac{\partial^{2} \Psi}{\partial t^{2}}\right]
$$

Persamaan di atas memiliki solusi ketika kedua bagian di dalam kurung siku bernilai nol. Sehingga didapatkan dua persamaan gelombang

$$
\frac{(\lambda+2 \mu)}{\rho} \nabla^{2} \Phi=\frac{\partial^{2} \Phi}{\partial t^{2}}
$$

dan,

$$
\frac{\mu}{\rho} \nabla^{2} \Psi=\frac{\partial^{2} \Psi}{\partial t^{2}}
$$

sehingga akhirnya didapat hubungan $\Phi=\sqrt{\frac{\lambda+2 \mu}{\rho}}$ dan $\Psi=\sqrt{\frac{\mu}{\rho}}$

Gelombang $\Phi$ merupakan gelombang yang tak memiliki komponen torsi, sehingga biasa disebut juga dengan gelombang dilatasi, longitudinal, irrotational, atau kompresi. Gelombang ini disebut gelombang primer, atau gelombang $\mathrm{P}$, karena biasanya gelombang ini datang lebih awal. Gelombang $\Psi$ biasa disebut dengan gelombang geser, transversal, atau rotational. Gelombang ini disebut dengan gelombang sekunder, atau gelombang S, karena kecepatannya yang lebih kecil dibandingkan gelombang $\mathrm{P}$, sehingga gelombang ini biasanya datang setelah gelombang $\mathrm{P}$.

\subsection{Persamaan Eikonal dan transport}

Gelombang elastik merambat dalam medium dengan parameter elastik yang bervariasi terhadap ruang. Dengan mengasumsikan frekuensi tinggi, maka digunakan Persamaan (11) dan (12) untuk gelombang P dan S. Persamaan eikonal dan transport yang terkait diturunkan dengan menggunakan asumsi gelombang menjalar pada medium heterogen dan isotropik. Jika solusi Persamaan (11) diasumsikan bersifat harmonik harmonik,

$$
\Phi=A(X) \exp [-i \omega(T(x)+)]
$$

di mana $\mathrm{T}(\mathrm{x})$ adalah fungsi fasa yang mendeskripsikan permukaan-permukaan dengan fase yang sama, maka substitusi Persamaan (13) ke dalam (11) akan didapatkan

$$
\nabla^{2} A-\omega^{2} A|\nabla T|^{2}-i\left[2 \omega \nabla A . \nabla T+\omega A \nabla^{2} T\right]=\frac{-A \omega^{2}}{\alpha}
$$




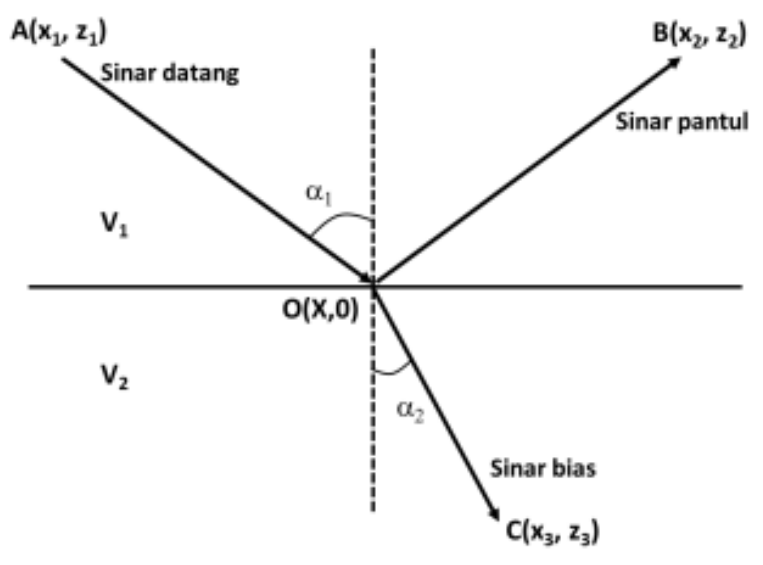

Gambar 1. Pemantulan dan pembiasan gelombang pada batas medium

di mana $\alpha^{2}=\frac{\lambda+2 \mu}{\rho}$. Dengan menginspeksi bagian real persamaan di atas, akan didapatkan hubungan

$$
\frac{-\nabla^{2} A}{\omega^{2}}+|\nabla T|^{2}=\frac{1}{\alpha^{2}}
$$

Dengan mengambil asumsi bahwa frekuensi osilasi bernilai, maka didapatkan persamaan eikonal $|\nabla T|^{2}=\frac{1}{\alpha^{2}}$ atau

$$
|\nabla T|=\frac{1}{\alpha}
$$

yang merupakan persamaan persoalan syarat batas. Bagian imajiner Persamaan (14) tidak lain merupakan persamaan transport berbentuk

$$
2 \nabla A . \nabla T+A \nabla^{2} T=0
$$

Fungsi $T(x)$ memiliki satuan waktu dan merepresentasikan waktu yang dibutuhkan oleh gelombang untuk berpindah dari suatu titik referensi $x_{0}$ ke titik $\mathrm{x}$. Sehingga, titik-titik yang memiliki nilai $\mathrm{T}$ yang sama, $\mathrm{T}(\mathrm{x})$ $=$ konstanta, akan membentuk muka gelombang. Sedangkan $\nabla T(x)$ menunjukkan perubahan $\mathrm{T}(\mathrm{x})$ terhadap ruang yang menunjukkan lintasan sinar (raypath) gelombang.

\subsection{Prinsip Fermat}

Prinsip Fermat adalah sebuah prinsip yang mendasari lintasan dari sinar gelombang. Prinsip ini mengatakan bahwa lintasan yang ditempuh oleh suatu sinar gelombang antara dua titik adalah lintasan dengan waktu tercepat. Secara matematis hal ini diungkapkan sebagai

$$
T_{A B}=\int_{A}^{B} \frac{d s}{v}=\text { ekstremum }
$$

Prinsip Fermat merupakan dasar dari pemantulan dan pembiasan sinar gelombang pada batas antara dua medium medium, seperti pada Gambar 1. Pada kasus pemantulan,

$T_{A B}=\int_{A}^{B} \frac{d s}{v}=\frac{1}{v}\left(\sqrt{\left(X-x_{1}\right)^{2}+z_{1}^{2}}+\sqrt{\left(x_{2}-X\right)^{2}+z_{2}^{2}}\right)$ menurut prinsip Fermat, lintasan yang dilewati sinar gelombang merupakan lintasan dengan waktu stasioner, sehingga

$$
\frac{d T}{d x}=0
$$

atau,

$$
\begin{gathered}
\frac{1}{v}\left(\frac{X-x_{1}}{\sqrt{\left(X-x_{1}\right)^{2}+z_{1}^{2}}}-\frac{x_{2}-X}{\sqrt{\left(x_{2}-X\right)^{2}+z_{2}^{2}}}\right)=0 \\
\frac{X-x_{1}}{\sqrt{\left(X-x_{1}\right)^{2}+z_{1}^{2}}}=\frac{x_{2}-X}{\sqrt{\left(x_{2}-X\right)^{2}+z_{2}^{2}}}
\end{gathered}
$$

yang berarti,

$$
\sin \alpha_{\text {refelction }}=\sin \alpha_{1}
$$

yang tidak lain adalah Hukum Snell untuk pemantulan. Pada kasus pembiasan ungkapan Persamaan (20) akan berbentuk

$T_{A C}=\int_{A}^{C} \frac{d s}{v}=\left(\frac{\sqrt{\left(X-x_{1}\right)^{2}+z_{1}^{2}}}{v_{1}}\right)+\left(\frac{\sqrt{\left(x_{3}-X\right)^{2}+z_{3}^{2}}}{v_{2}}\right)$

dan dengan menggunakan prinsip Fermat kembali, didapatkan

$$
\frac{1}{v_{1}} \frac{X-x_{1}}{\sqrt{\left(X-x_{1}\right)^{2}+z_{1}^{2}}}=\frac{1}{v_{2}} \frac{x_{3}-X-}{\sqrt{\left(x_{3}-X\right)^{2}+z_{3}^{2}}}
$$

atau,

$$
\frac{\sin \alpha_{1}}{v_{1}}=\frac{\sin \alpha_{2}}{v_{2}}
$$

yang merupakan hukum Snell untuk pembiasan.

Terlihat bahwa dengan menggabungkan prinsip Fermat dan persamaan eikonal, maka dimungkinkan untuk menentukan lintasan gelombang seismic untuk kasus yang lebih umum (kasus 3D) dengan kecepatan yang bervariasi dan batas antar medium.

\section{EVOLUSI PERMUKAAN}

Evolusi permukaan merupakan fenomena yang teramati pada berbagai bidang. Seluruh jenis gelombang ataupun penjalaran api dapat diinterpretasikan sebagai evolusi dari permukaan.

\subsection{Evolusi Permukaan Batas}

Untuk suatu daerah seperti yang dicontohkan pada Gambar $2 \mathrm{a}$, permukaan batas (atau disebut juga bidang batas) didefinisikan sebagai suatu kurva (kasus 2D) atau permukaan (kasus 3D) yang memisahkan area di dalam daerah dengan di luar daerah. Pada evolusi permukaan batas, terdapat dua jenis gerakan permukaan batas yaitu gerakan yang hanya membesar atau mengecil, direpresentasikan oleh Persamaan (24) yang merupakan persoalan syarat batas; dan gerakan yang membuat permukaan membesar dan mengecil, direpresentasikan oleh Persamaan (25) yang merupakan persoalan syarat awal (Dicker, 2006):

$$
F|\nabla T|=1,
$$




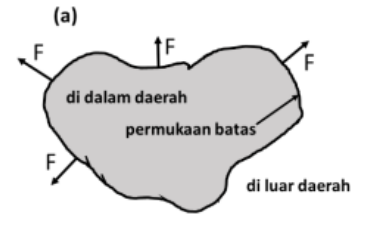

(b)

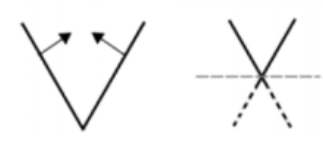

Gambar 2. (a) Contoh permukaan batas, F merupakan kecepatan propagasidari permukaan batas; (b) Irisan dua buah kurva dan pemotongan untuk menghasilkan permukaan batas yang baik (Dicker, 2006)

$$
\Phi+F|\nabla \Phi|=0
$$

Pada tahap komputasi evolusi permukaan batas, informasi dari titik selanjutnya tidak diketahui, sehingga hanya informasi dari titik sebelumnya yang dapat digunakan untuk menentukan evolusi yang terjadi selanjutnya. Dengan kata lain, skema numerik yang digunakan haruslah menggunakan nilai upwind dengan baik. Nilai upwind adalah nilai pada sisi dalam daerah, sedangkan downwind di luar daerah (Rawlinson dan Sambridge, 2004; Sethian dan Popovici, 1999).

\subsection{Kondisi Entropi dan Solusi Viskositas}

\subsubsection{Kondisi Entropi}

Dalam evolusi permukaan batas, terdapat kemungkinan dua buah kurva beririsan, yang mengakibatkan ketidakjelasan permukaan batas. Ketika itu terjadi, maka harus dilakukan pemotongan salah satu bagian dari kedua kurva tersebut seperti yang diperlihatkan pada Gambar 2b. Karena itu, harus terdapat kondisi tertentu yang diberikan pada solusi yang akan dibentuk dari evolusi permukaan batas. Kondisi tersebut berguna untuk membatasi agar tidak ada informasi baru yang dibuat selama propagasi gelombang. Kondisi tersebut disebut dengan kondisi entropi. Salah satu cara agar kondisi entropi terpenuhi adalah dengan memanfaatkan prinsip Huygen. Dengan mengambil setiap titik sebagai sumber gelombang baru untuk berpropagasi, kemudian mengambil hanya gelombang yang datang pertama kali, maka tidak akan terjadi irisan kurva seperti kasus sebelumnya.

\subsubsection{Solusi viskositas}

Selain kemungkinan beririsan, dalam propagasi gelombang tidak ada jaminan bahwa kurva yang dihasilkan selalu halus. Jika suku penghalus $\epsilon$ ditambahkan pada persamaan permukaan yang berevolusi jelas akan melanggar kondisi entropi. Namun, jika $X_{\text {curvature }}^{\epsilon}(t)$ adalah solusi dari fungsi kecepatan $F=1-\epsilon \kappa$ dengan $\kappa$ merupakan kurvatur pada suatu titik, dan $X_{\text {constant }}(t)$ merupakan solusi menggunakan $\mathrm{F}=1$, maka

$$
\forall T, \lim _{\epsilon \rightarrow 0} X_{\text {curvature }}^{\epsilon}(t)=X \text { constant }(t)
$$

menunjukkan bahwa pada limit $\epsilon$ menuju 0, fungsi kecepatan $F$ dengan bagian penghalus $\epsilon \kappa$, merupakan solusi yang

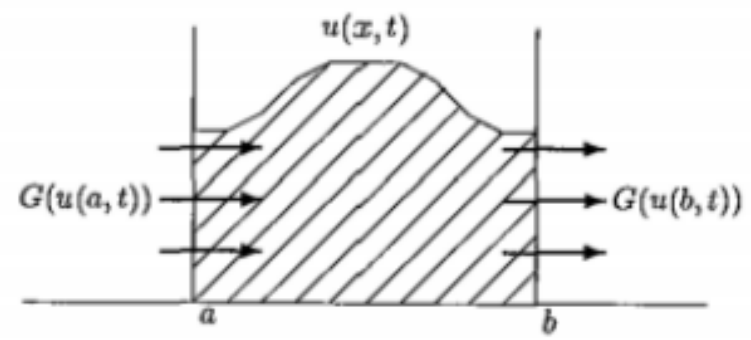

Gambar 3. Flux G dari fungsi u pada interval [a, b] (Sethian, 2005).

memenuhi kondisi entropi. Limit ini disebut sebagai limit viscous dan solusinya yang memenuhi kondisi entropi disebut dengan solusi viskositas. Disebut dengan solusi viskositas, karena penggunaan suku viskositas fluida difusiv pada hukum kekekalan hiperbolik (Dicker, 2006).

\subsection{Persamaan Hamilton-Jacobi}

Persamaan (24) dan (25) dapat ditulis dalam persamaan Hamilton-Jacobi yang berbentuk

$$
H+\frac{\partial S}{\partial t}=0
$$

di mana $H=H(q 1, \ldots, q N ; \partial S / \partial q 1, \ldots, \partial S / \partial q N ; t)$ adalah Hamiltonian klasik dan $S=S(q 1, \ldots, q N, t)$ adalah fungsi utama Hamilton atau fungsi aksi. Hamiltonian yang memenuhi persamaan di atas adalah persamaan syarat awal

$$
H\left(S_{x}, S_{y}, S_{z}, x, y, z\right)=F \sqrt{S_{x}^{2}+S_{y}^{2}+S_{z}^{2}}
$$

dan persamaan syarat batas

$$
H\left(S_{x}, S_{y}, S_{z}, x, y, z\right)=F \sqrt{S_{x}^{2}+S_{y}^{2}+S_{z}^{2}}-1
$$

yang untuk kasus satu dimensi (1D) akan berbentuk

$$
H\left(S_{x}\right)+S_{t}=0
$$

Dengan mendiferensiasi Persamaan (30) dan memisalkan $s=S_{x}$, maka didapatkan hukum kekekalan hiperbolik

$$
[H(s)]_{x}+s_{t}=0
$$

Jika suku difusi ditambahkan, maka persamaan (31) menjadi

$$
[H(s)]_{x}+s_{t}=\epsilon \nabla^{2} s
$$

\subsection{Hukum Kekekalan Hiperbolik}

Persamaan (31) memiliki bentuk yang sama dengan persamaan kontinuitas

$$
\frac{\partial \rho}{\partial t}+\nabla \cdot J=0
$$

atau pada kasus $1 \mathrm{D}$ berbentuk $\rho_{t}+J_{x}=0$,

sehingga pada Persamaan (31), perubahan s pada suatu interval $[\mathrm{a}, \mathrm{b}]$ sama dengan flux $\mathrm{H}(\mathrm{s})$ yang mengalir pada interval tersebut. Dalam hal ini besaran s merupakan besaran yang kekal. Oleh karena itu, skema numerik yang digunakan mestilah dalam bentuk konservatif (Sethian, 2005). Suatu 
skema numerik memiliki bentuk konservatif jika terdapat fungsi fluks numerik $\left(s_{i-1}\right)\left(h\left(s_{i}, s_{i+1}\right)\right)$ yang mengaproksimasi nilai untuk $H_{1-1 / 2}\left(H_{i+1 / 2}\right)$ sehingga

$$
\frac{S_{i}^{n+1}-S_{i}^{n}}{\Delta t}=-\frac{H_{i+1 / 2}-H_{i-1 / 2}}{\Delta x}
$$

Selain itu, menurut Sod (1985) dan LeVeque (1992), skema konservatif dan monoton menghasilkan solusi yang memenuhi kondisi entropi. Sehingga dengan menentukan suatu fungsi fluks numerik h dan memeriksa kemonotonannya, maka kondisi entropi akan terpenuhi. Pada kasus spesifik dari persamaan gelombang non-linear yaitu Persamaan (31) dengan $H(s)=f\left(s^{2}\right)$ dapat digunakan skema berdasarkan Osher dan Sethian (1988),

$$
h\left(s_{j}^{n}, s_{j+}^{n}\right)=f\left(\left(\max \left(s_{j}^{n}, 0\right)\right)^{2}+\left(\min \left(s_{j+1}^{n}, 0\right)\right)^{2}\right)
$$

yang memenuhi solusi viskositas.

\section{MASALAH SYARAT BATAS: METODE STASIONER}

Pemecahan persamaan eikonal memerlukan syarat batas sehingga persamaan yang berkaitan adalah Persamaan (24) dan (29). Agar Persamaan (30) memenuhi bentuk konservatif maka digunakan Persamaan (34) sehingga

$$
\frac{s_{i}^{n+1}-s_{i}^{n}}{\Delta t}=-\frac{h\left(s_{i}^{n}, s_{i+1}^{n}\right)-h\left(s_{i-1}^{n}, s_{i}^{n}\right)}{\Delta x}
$$

Persamaan di atas dikerjakan dengan menggunakan aproksimasi fungsi fluks numerik, h,

$$
\begin{aligned}
& H i-1 / 2 \approx h\left(s_{i-1}^{n}, s_{i}^{n}\right) \\
& H i+1 / 2 \approx h\left(s_{i}^{n}, s_{i+1}^{n}\right)
\end{aligned}
$$

Ruas kanan Persamaan (36) merupakan operator diferensiasi tengah yang bekerja pada fungsi h. Ketika ukuran grid menuju 0, maka $h(s, s)=H(s)$. Skema persamaan Hamilton-Jacobi 1D menjadi

$$
\begin{gathered}
S_{t}=-H(s) \\
S_{i}^{n}+1=S^{n}-\Delta t H(s)
\end{gathered}
$$

di mana $H(s)$ didekati dengan fungsi fluks numerik

$$
H\left(s_{i}^{n} \approx h\left(s_{i-1 / 2}, s_{i+1 / 2}\right)\right.
$$

sehingga

$$
S_{i}^{n+1}=S^{n}-\Delta \operatorname{th}\left(s_{i-1 / 2}, s_{i+1 / 2}\right)
$$

Karena $s=S_{x}$ maka $s_{i-1 / 2}=\left(S_{x}\right)_{i-1 / 2}=\frac{S_{i}-S_{i-1}}{\Delta}=$ $D^{-x} S$ dimana dalam hal ini digunakan definisi

$$
\begin{aligned}
& D^{+x}=\frac{S_{i+1}-S_{i}}{\Delta x} \\
& D^{-x}=\frac{S_{i}-S_{i-1}}{\Delta x} \\
& D^{0 x}=\frac{S_{i+1}-S_{i-1}}{\Delta x}
\end{aligned}
$$

Sehingga diperoleh,

$$
S_{i}^{n+1}=S^{n}-\Delta t h\left(D^{-x} S_{i}^{n}, D^{+x} S_{i}^{n}\right)
$$

Pada kasus persamaan eikonal, diambil $S=T$, sehingga persamaan Hamilton-Jacobi menjadi

$$
H\left(T_{x}, T_{y}, T_{z}, x, y, z\right)=0
$$

Dengan menggunakan aproksimasi fungsi fluks numerik dan mengekspansinya ke persoalaan 3D, maka didapat

$$
\begin{aligned}
H\left(T_{x}, T_{y}, T_{z}\right) \approx h\left(D^{-x} T,\right. & D^{+x} T, D^{-y} T, \\
& \left.D^{+y} T, D^{-z} T, D^{+z} T\right)=0
\end{aligned}
$$

Karena , sesuai dengan persamaan (23), maka dapat digunakan fungsi fluks numerik pada Persamaan (29), sehingga didapatkan skema numerik (Rouy dan Tourin, 1992)

$$
\begin{aligned}
{\left[\operatorname { m a x } \left(D_{i j k}^{-x} T,-\right.\right.} & \left.D_{i j k}^{+x} T, 0\right) \\
& +\max \left(D_{i j k}^{-y} T,-D_{i j k}^{+y} T, 0\right) \\
& \left.+\max \left(D_{i j k}^{-z} T,-D_{i j k}^{+z} T, 0\right)\right]^{1 / 2}=\frac{1}{F_{i j k}}
\end{aligned}
$$

di mana $(i, j, k)$ adalah variabel-variabel penambahan grid Cartesian dalam $(x, y, z)$, sedangkan variabel bilangan bulat $a, b, c, d, e, f$ mendefinisikan orde akurasi operator beda hingga upwind yang digunakan dalam setiap kasus (Rawlinson dan Sambridge, 2005).

\section{FAST MARCHING METHOD}

Fast Marching Method (FMM) adalah sebuah metode untuk menyelesaikan persamaan eikonal dengan syarat $\alpha$ tidak negatif. Dengan menggunakan FMM, persamaan eikonal yang merupakan masalah syarat batas, dapat diselesaikan dengan satu kali iterasi.

\subsection{Kausalitas dan Solusi Persamaan (47)}

Ide utama dari FMM adalah untuk membentuk solusi secara sistematis dengan hanya menggunakan nilai upwind. Perhatikan bahwa Persamaan (44) memperbolehkan propagasi informasi satu arah, yaitu dari nilai $\mathrm{T}$ yang lebih kecil ke yang lebih besar. Fast Marching Method bekerja dengan membentuk solusi dari nilai $\mathrm{T}$ yang paling kecil, menjauhi syarat batas ke arah downwind. Sebelum menuju ke algoritma FMM, akan diturunkan terlebih dahulu solusi dari persamaan (47).

\subsubsection{Solusi Persamaan (47)}

Untuk menyelesaikan Persamaan (47) perlu dihilangkan terlebih dahulu fungsi max dari persamaan tersebut. Misalkan pada kasus di bawah ini pada sumbu x (Gambar 4):

$$
\begin{aligned}
& \max \left(D_{i j k}^{-x} T,-D_{i j k}^{+x} T, 0\right)= \\
& \max \left(\frac{X-T_{4}}{d x}, \frac{T_{2}-X}{d x}, 0\right) \\
& \quad \operatorname{atau} \\
& =\max \left(\frac{X-T_{4}}{d x}, \frac{X-T_{2}}{d x}, 0\right)
\end{aligned}
$$




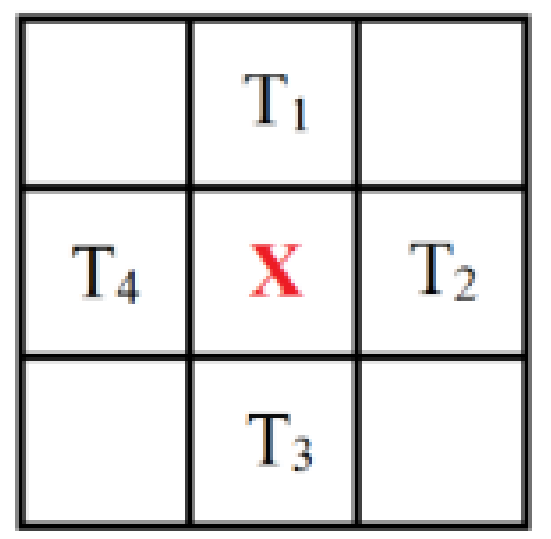

Gambar 4. Matriks nilai tetangga

$$
\begin{aligned}
\max \left(D_{i j k}^{-x} T,-D_{i j k}^{+x} T, 0\right) & = \\
& \max \left(\frac{X-\min \left(T_{4}, T_{2}\right)}{d x}, 0\right)
\end{aligned}
$$

Dengan menggunakan Persamaan (49) dan membatasi pada kasus 2D, maka Persamaan (47) akan menjadi

$$
\begin{aligned}
& \max \left(\frac{X-\min \left(T_{4}, T_{2}\right)}{d x}, 0\right)^{2} \\
& \quad+\max \left(\frac{X-\min \left(T_{1}, T_{3}\right)}{d y}, 0\right)^{2}=\frac{1}{F_{i j}^{2}}
\end{aligned}
$$

Misalkan $x_{\min }=\min \left(T_{4}, T_{2}\right)$ dan $y_{m} i n=\min \left(T_{3}, T_{1}\right)$, serta diasumsikan $X-x_{\min }>0$ dan $X-y_{\min }>0$ atau,

$$
\begin{aligned}
\left(\frac{1}{d x^{2}}+\frac{1}{d y^{2}}\right) X^{2}- & 2\left(\frac{x_{m i n}}{d x^{2}}+\frac{y_{\text {min }}}{d y^{2}}\right) X \\
+ & \left(\frac{x_{m i n}^{2}}{d x^{2}}+\frac{y_{m i n}^{2}}{d y^{2}}-\frac{1}{F_{i j}^{2}}\right)=0
\end{aligned}
$$

Persamaan di atas memiliki solusi jika nilai diskriminannya tidak negatif, $D \geq 0$

$$
X=\frac{-b+\sqrt{b^{2}-4 a c}}{2 a}
$$

dimana $a=\frac{1}{d x^{2}}+\frac{1}{d y^{2}}, b=-2\left(\frac{x_{\text {min }}}{d x^{2}}+\frac{y_{\text {min }}}{d y^{2}}\right)$, dan $c=$ $\left(\frac{x_{m i n}^{2}}{d x^{2}}+\frac{y_{m i n}^{2}}{d y^{2}}-\frac{1}{F_{i j}^{2}}\right)$

Pada kasus $D<0$, maka disimpulkan bahwa asumsi yang digunakan salah, di mana kasusnya adalah $X-x_{\text {min }}<$ 0 atau $X-y_{\min }<0$. Karena salah satu harus memenuhi, maka $X=y_{\text {min }}+\frac{d y}{F_{i j}}$ atau $X=x_{\text {min }}+\frac{d x}{F_{i j}}$ dengan $y_{\text {min }}<$ $x_{\text {min }}$ atau $x_{\text {min }}<y_{\text {min }}$. Hasil di atas dapat ditulis kembali menjadi

$$
X=\min \left(x_{\min }, y_{\min }\right)+\frac{d x(\operatorname{ataudy})}{F_{i j}}
$$

\subsubsection{FMM dengan Akurasi Lebih Tinggi}

Untuk mendapatkan akurasi yang lebih tinggi dari FMM, maka perlu ditambahkan suku-suku dengan orde lebih tinggi. Untuk aproksimasi backward hingga orde kedua, turunan pertama, $T_{x}$, akan berbentuk

$$
T_{x} \approx \frac{3 T_{i}-4 T_{i-1}+T_{i-2}}{2 \Delta x}
$$

yang dapat ditulis kembali menjadi

$$
T_{x} \approx D^{-x} T+\frac{\Delta x}{2} D^{-x-x} T
$$

Bentuk yang sama berlaku untuk aproksimasi forward,

$$
T_{x} \approx D^{+x} T+\frac{\Delta x}{2} D^{+x+x} T
$$

Untuk mempertahankan kemonotonan dari T, maka harus dipenuhi $T_{i-2} \leq T_{i-l}$ untuk backward difference atau $T_{i+2} \leq$ $T_{i+1}$ untuk forward difference sedemikian sehingga diperkenalkan fungsi switch:

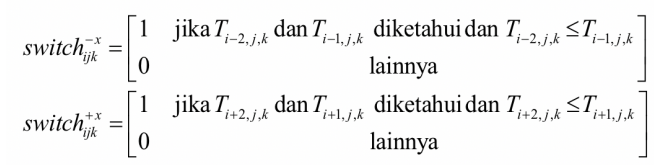

Fungsi switch berguna untuk memindahkan skema perhitungan menjadi orde satu jika syarat monoton tidak terpenuhi. Dengan menggunakan aproksimasi orde dua dan fungsi switch, maka Persamaan (47) dapat diubah menjadi

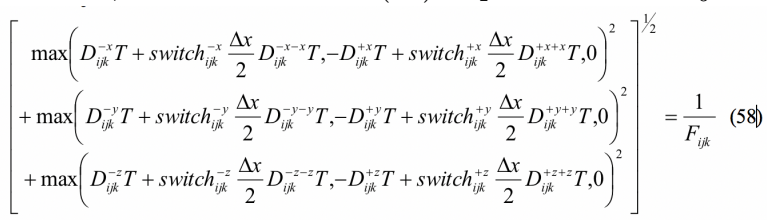

Jika dimisalkan tetangga terkecil dari $\mathrm{T}$ adalah xmin1 dan ymin1, untuk orde dua dibutuhkan titik selanjutnya dari $x_{m i n 1}$ dan $y_{m i n 1}$ tersebut misalkan $x_{\min 2}$ dan $y_{\text {min } 2}$. Jika keempat titik tersebut memenuhi syarat monoton, maka Persamaan (58) menjadi

$$
\begin{aligned}
& \frac{9}{4}\left(\frac{1}{d x^{2}}+\frac{1}{d y^{2}}\right) X^{2}+\left(\frac{-6 x_{\min 1}+\frac{3}{2} x_{\min 2}}{d x^{2}}+\frac{-6 y_{\min 1}+\frac{3}{2} y_{\min 2}}{d y^{2}}\right) X \\
& +\left(\frac{4 x_{\min 1}^{2}-2 x_{\min 1} x_{\min 2}+\frac{1}{4} x_{\min 2}}{d x^{2}}+\frac{4 y_{\min 1}^{2}-2 y_{\min 1} y_{\min 2}+\frac{1}{4} y_{\min 2}}{d y^{2}}-\frac{1}{F^{2}}\right)=0 .
\end{aligned}
$$

Persamaan (59) akan menghasilkan solusi real, jika $D \leq 0$. Pada kasus $D<0$, maka skema akan dikembalikan lagi menjadi orde satu. Sehingga dengan menggunakan skema ini, didapatkan solusi yang merupakan gabungan orde satu dan orde dua. Keakuratan akan meningkat sebanding dengan banyaknya titik yang memenuhi skema orde dua.

\subsection{Algoritma FMM}

Misalkan pada kasus persamaan eikonal 2D di mana syarat batas berada di tengah, diperlihatkan oleh bola hitam (Known) pada Gambar 5a (Sethian, 2005). Bola berwarna putih adalah nilai yang tidak diketahui, daerah Far, sedangkan bola berwarna abu merupakan titik bernilai Trial. Algoritma dimulai dengan menghitung nilai $\mathrm{T}$ dari keempat 
tetangga dari titik syarat batas tersebut menggunakan solusi Persamaan (47).

Perhitungan ini memberikan kemungkinan nilai pada keempat tetangga tersebut. Kemudian FMM akan berpropagasi dari titik Trial ini ke arah downwind. Titik Trial dengan nilai $\mathrm{T}$ terkecil memiliki nilai yang telah benar, karena upwinding tidak mempengaruhi titik dengan tetangga yang memiliki nilai lebih besar. Sehingga titik tersebut diterima, menjadi Known, dan kemudian algoritma dijalankan kembali dari titik tersebut. Karena perhitungan ulang nilai $\mathrm{T}$ pada tetangga downwind tidak dapat menghasilkan nilai yang lebih kecil dari nilai yang diketahui, maka FMM dapat terus bergerak maju. FMM menghitung solusi bergerak keluar dari syarat batas, selalu mengubah nilai Trial terkecil menjadi nilai Known, dan menghitung kembali nilai dari tetangga downwind sehingga kita tidak membutuhkan untuk kembali dan mengubah nilai dari Known. Nilai tersebut tidak akan berubah oleh seluruh perhitungan selanjutnya. Cara lain untuk melihat FMM adalah setiap titik Trial minimum memulai aplikasi prinsip Huygen dan mengembangkan muka gelombang dan memperbarui titik-titik lainnya (Sethian, 2005).

Dapatlah disimpulkan bahwa FMM bekerja sebagai berikut: tandai syarat batas sebagai Known; tandai seluruh tetangga berjarak satu grid sebagai Trial; tandai titik lainnya sebagai Far. Kemudian lakukan loop, yaitu: (i) Ambil titik dari Trial dengan $\mathrm{T}$ minimum, $\left(i_{\min }, j_{\min }\right)$. (ii) Pindahkan titik $\left(i_{m i n}, j_{m i n}\right)$ ke Known. (iii) Tandai sebagai Neighbors titik antara $\left(i_{m i n+1}, j_{m i n}\right),\left(i_{m i n-1}, j_{m i n}\right)$, $\left(i_{m i n}, j_{m i n+1}\right),\left(i_{m i n}, j_{m i n-1}\right)$ yang berada pada Narrow Band atau Far. Jika titik pada Neighbors berada pada Far, maka titik tersebut dipindahkan ke Trial. (iv) Hitung ulang semua nilai T dari Neighbors dengan menyelesaikan persamaan kuadrat (2.50) dan memilih solusi terbesar. (v) Mulai kembali ke (1) hingga semua titik berada di Known.

Seperti pada Gambar 5b, FMM bergerak melalui daerah tipis berisi nilai Trial. Lapisan tipis ini bergerak ke arah downwind mengambil titik-titik baru dari daerah Far, sedangkan titik yang telah dilewati telah memiliki nilai yang tetap. Pergerakan ini berpusat pada titik Trial dengan nilai T minimum. Sehingga, kunci efisiensi metode ini berada pada skema penentuan nilai minimum tersebut.

\subsection{Struktur Data Min-Heap dan Efisiensi Komputasi}

Algoritma FMM hanya membutuhkan nilai terkecil dari titik-titik pada Trial. Sehingga agar mendapatkan hasil yang efisien, tidak perlu menggunakan algoritma yang menyusun seluruh nilai dari yang terkecil ke yang terbesar, cukup algoritma yang dapat menentukan nilai minimum secara cepat. Metode yang tepat untuk tujuan tersebut adalah dengan menyusun data nilai Trial dalam sebuah struktur data minheap.

Struktur data min-heap adalah struktur data berbentuk pohon biner (binary tree) dengan sifat bahwa nilai pada tiap simpul lebih kecil atau sama dengan nilai dari kedua cabangnya seperti yang diilustrasikan pada Gambar 5c. Dalam penggunaannya, struktur heap akan lebih efisien jika direpresentasikan menggunakan array dengan simpul pada lokasi $\mathrm{k}$ dan cabang pada $2 \mathrm{k}$ dan $2 \mathrm{k}+1$. Dengan definisi ini, maka simpul dari suatu cabang $\mathrm{k}$ adalah bk/2c. Sehingga akar,
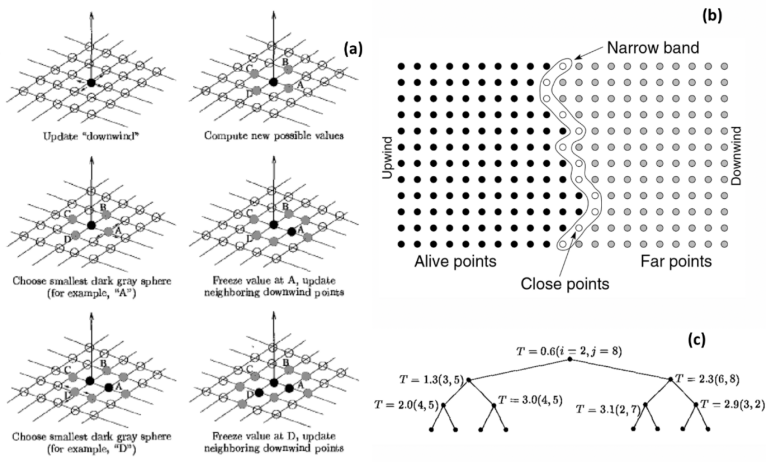

Gambar 5. (a) Prosedur FMM (Sethian, 2005); (b) Struktur narrow band (Rawlinson dan Sambridge, 2005); (c) Contoh struktur min-heap (Sethian, 2005).

yang memiliki nilai paling kecil, tersimpan pada lokasi $\mathrm{k}=$ 1.

Struktur heap ini akan berubah untuk setiap loop, sehingga dibutuhkan perintah untuk mempertahankan sifat dari heap. Terdapat empat perintah yang digunakan dalam FMM yaitu UpHeap, DownHeap, Insert, dan FindSmallest.

- UpHeap: perintah yang berfungsi untuk menaikkan anggota heap selama nilainya lebih kecil dari atau sama dengan simpulnya

- DownHeap: perintah ini akan menurunkan anggota heap selama nilainya lebih besar dibandingkan cabangnya.

- Insert: perintah ini berfungsi untuk memasukkan anggota baru ke dalam heap dan kemudian menyusunnya kembali. Anggota baru tersebut dimasukkan ke posisi $\mathrm{N}$ +1 dan kemudian digerakkan dengan perintah UpHeap. Dalam FMM, perintah ini digunakan ketika suatu titik dipindahkan dari Far ke Trial.

- FindSmallest: Perintah ini berfungsi untuk mengambil nilai terkecil (akar), $\mathrm{k}=1$, dari heap. Akar diambil kemudian ditukar dengan posisi N. Posisi N yang berisi nilai terkecil kemudian dihilangkan dilakukan DownHeap terhadap posisi 1. Perintah ini digunakan pada FMM untuk menentukan nilai minimum dari Trial pada awal loop dan kemudian menghapusnya dari himpunan Trial untuk dipindahkan ke Known.

\subsection{Aplikasi Heap pada FMM dan Efisiensinya}

Langkah pertama dari FMM adalah dengan mencari nilai terkecil dari struktur Narrow Band. Hal ini dilakukan dengan menggunakan fungsi FindSmallest. Setelah itu tetangga Far dari nilai terkecil diubah menjadi Trial dan dimasukkan ke struktur heap dengan operasi Insert. Kemudian setiap titik dari tetangga nilai terkecil diperbarui nilainya dan dilakukan operasi UpHeap untuk mempertahankan sifat heap.

Operasi UpHeap dan DownHeap pada kasus terburuk akan membawa suatu anggota heap dari paling atas ke paling bawah, atau sebaliknya. Sehingga operasi ini akan menghabiskan waktu dengan orde $\mathrm{O}(\log \mathrm{M})$ dengan asumsi terdapat $\mathrm{M}$ anggota heap. Pada FMM, setiap titik hanya akan dilewati satu kali sehingga total operasi pada kasus terburuk memiliki orde $\mathrm{N} \log (\mathrm{N})$, di mana $\mathrm{N}$ adalah jumlah titik pada grid. 


\subsubsection{Ray Tracing}

Setelah waktu tempuh dihitung dengan menggunakan FMM, maka untuk menyelesaikan masalah propagasi gelombang seismik pada medium perlu juga ditentukan lintasan propagasinya. Lintasan gelombang seismik mematuhi prinsip Fermat, yaitu lintasan dengan waktu minimum. Sehingga dengan menentukan nilai minimum dari tetangga pada detector kemudian menyusuri terus hingga ke sumber, maka lintasan dapat ditentukan.

Lintasan Diskrit Algoritma untuk menentukan lintasan dapat diurutkan sebagai berikut:

[1] Tentukan titik akhir dari lintasan, $(x, y)$

[2] Tentukan tetangga dengan nilai $\mathrm{T}$ terkecil dari $(x, y)$ yaitu (xmin, ymin)

[3] Buat garis dari $(x, y)$ ke (xmin,ymin)

[4] Ambil (xmin,ymin) sebagai $(x, y)$ yang baru

[5] Kembali ke no. 2 hingga $(x, y)$ berada pada sumber

Lintasan Kontinu Algoritma di atas menghasilkan bentuk lintasan yang diskrit. Sehingga gambaran terhadap lintasan gelombang tidak begitu tepat. Untuk meningkatkan kualitas bentuk lintasan, maka perlu dibentuk lintasan kontinu dengan mengikuti arah dari $\nabla T$. Algoritma untuk menentukan lintasan menjadi berikut:

[1] Tentukan titik akhir dari lintasan, $(x, y)$

[2] Tentukan tetangga dengan nilai $\mathrm{T}$ terkecil dari $(x, y)$ pada sumbu $x,\left(x_{\min }, y\right)$, dan pada sumbu $y,\left(x, y_{\text {min }}\right)$

[3] Hitung $\nabla T /|\nabla T|$ dengan menggunakan titik minimum, $\left(x_{\text {min }}, y\right)$ dan $\left(x, y_{\text {min }}\right)$, dan buat lintasan dari $(\mathrm{x}, \mathrm{y}) \mathrm{ke}$ arah tersebut

[4] Ambil titik tersebut sebagai (x, y) yang baru

[5] Kembali ke no. 2 hingga (x, y) berada pada sumber

\subsubsection{Pembiasan dan Pemantulan Gelombang Seismik Menggunakan FMM}

FMM akan digunakan untuk menghitung waktu tempuh gelombang seismik yang mengalami pemantulan dan pembiasan. Pada kasus pembiasan, perhitungan waktu tempuh dapat dilakukan tanpa algoritma tambahan karena dalam pembiasan setiap titik tetap dilalui hanya sekali. Sedangkan pada pemantulan, maka titik menjadi dilalui dua kali. Oleh karena itu, pada kasus pemantulan digunakan algoritma:

[1] Tentukan titik akhir dari lintasan, $\left(x_{1}, y_{1}\right)$

[2] Lakukan FMM dengan titik $\left(x_{1}, y_{1}\right)$ sebagai sumber untuk mendapatkan $T_{2}$

[3] Tentukan lokasi nilai minimum, $\left(x_{\min }, y_{\min }\right)$, dari $T_{\text {total }}(x, y)=T_{1}(x, y)+T_{2}(x, y)$ terhadap variasi $(x, y)$ di mana $(x, y) \epsilon$ batas medium

[4] Lakukan RayTrace dari sumber ke $\left(x_{\min }, y_{\text {min }}\right)$, kemudian dari $\left(x_{\text {min }}, y_{\text {min }}\right)$ ke $\left(x_{1}, y_{1}\right)$

Dengan menggunakan algoritma di atas, maka lintasan dan waktu tempuh dari pemantulan dan pembiasan gelombang seismik dapat ditentukan oleh FMM.

\subsubsection{Penentuan Sumber Gelombang Seismik}

Menentukan titik sumber gempa atau hypocenter merupakan salah satu masalah inversi klasik dalam seismologi.
Hingga saat ini, hampir seluruh prosedur penentuan hypocenter berdasarkan pengolahan data waktu datang informasi dari sinyal seismik yang dihasilkan gempa. Akurasi penentuan hypocenter sangat vital dalam berbagai aplikasi seperti prediksi gempa, tomografi seismik, studi mekanisme sumber dan sebagainya. Jika dilakukan aproksimasi titik terhadap hypocenter, maka lokasi titik tersebut diwakilkan oleh empat parameter yakni dalam tiga koordinat spasial dan satu waktu kejadian yang dalam koordinat Cartesian dinyatakan dengan $\left(x, y, z, t_{0}\right)$, sedangkan dalam koordinat bola oleh $\left(r, \Theta, \phi, t_{0}\right)$. Salah satu kesulitan dalam menentukan hypocenter adalah ketika struktur kecepatan di bawah permukaan tidak diketahui. Dengan demikian, hakikatnya penentuan hypocenter dibagi ke dalam tiga langkah utama yaitu penentuan model kecepatan, penentuan titik hypocenter awal, dan terakhir relokasi gempa.

Yang mendasari persoalan inversi adalah hubungan antara data $\mathbf{d}$ dengan model $\mathbf{m}$,

$$
\mathbf{d}=\mathbf{g}(\mathbf{m}) \text {. }
$$

Pada persoalan ini, matrix $\mathbf{d}$ adalah waktu kedatangan gelombang seismik $T_{i}(i=1,2, \ldots, N)$ yang dihasilkan oleh gempa. Parameter model $\mathbf{m}$ adalah parameter hypocenter gempa atau $m=\left(x, y, z, t_{0}\right)$. Pada kasus di mana model kecepatan juga tidak diketahui, selain titik hypocenter, maka seringkali inversi dilaakukan terhadap hypocenter dan kecepatan secara bersamaan. Dalam pembahasan kali ini dimisalkan parameter model hanya merupakan parameter hypocenter saja.

Persoalan inversi pada intinya bertujuan untuk memodifikasi nilai parameter model $\mathrm{m}$ secara iteratif hingga data yang dibangkitkan oleh model sama dengan data observasi $d=d_{\text {obs }}$. Dengan demikian, persoalan inversi dapat dipandang sebagai persoalan minimisasi suatu fungsi objektif:

$$
S(\mathbf{m})=\left(\mathbf{d}_{\mathrm{obs}}-\mathbf{d}\right)^{T}\left(\mathbf{d}_{\mathrm{obs}}-\mathbf{d}\right)=\left\|\mathbf{d}_{\mathrm{obs}}-\mathbf{d}\right\|^{2} .
$$

Kegunaan FMM yang utama dalam persoalan ini adalah ketika proses modifikasi model, data waktu kedatangan dapat dengan mudah diperoleh tanpa perlu menentukan fungsi g. Hal di atas dicapai dengan menerapkan FMM terhadap seluruh detektor gempa sebagai syarat batas. Dengan demiian, data waktu tempuh d dari setiap titik ke setiap detektor dapat ditentukan dengan cepat. Persamaan (60) dapat diubah untuk mempermudah perhitungan ke dalam (Rawlinson, 2008):

$$
S(\mathbf{m})=\left(\mathbf{d}_{\mathrm{obs}}^{r}-\mathbf{d}^{r}\right)^{T}\left(\mathbf{d}_{\mathrm{obs}}^{r}-\mathbf{d}^{r}\right)
$$

di mana $d^{r}$ merupakan data yang telah dikurangi dengan rata-ratanya. Dengan mengurangi data observasi dengan rata-rata maka kebergantungan terhadap waktu kejadian gempa yang tidak diketahui dapat dihilangkan. Hal ini karena $d_{o b s}=d^{r}+d_{0}$ dimana $d_{0}$ adalah waktu kejadian dan $d^{r}$ adalah waktu tempuh. Dengan demikian,

$$
\begin{aligned}
& \mathbf{d}_{\mathrm{obs}}^{r}=\mathbf{d}_{\mathrm{obs}}-\mathbf{d}_{\mathrm{obs}}^{\text {mean }} \\
& \mathbf{d}_{o b s}^{r}=\mathbf{d}^{t}+d_{0}-\left(\frac{\sum_{i=1}^{N} d_{i}^{t}}{N}+d_{0}\right) \\
& \mathbf{d}_{o b s}^{r}=\mathbf{d}^{t}-\frac{\sum_{i=1}^{N} d_{i}^{t}}{N} .
\end{aligned}
$$

Pengurangan data dengan nilai rata-ratanya men- 


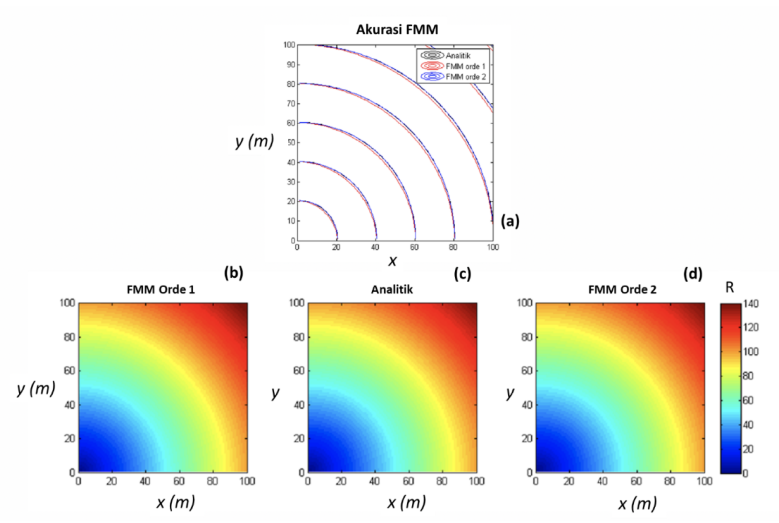

Gambar 6. Kontur jarak terhadap titik asal menggunakan FMM dengan grid 101x101 (atas) dan kontur distribusi jarak dari titik asal (bawah)

jadikan fungsi objektif hanya terkait dengan perbandingan informasi waktu tempuh saja. Setelah S(m) diminimumkan, maka waktu kejadian dapat diketahui dengan menghitung $d_{0}=d_{o b s}-d^{t}$. Waktu kejadian tidak mempengaruhi pola waktu kedatangan relatif sehingga tidak ada informasi yang diabaikan dengan pendekatan ini.

\section{HASIL PEMODELAN KE-DEPAN PERAMBATAN GELOMBANG SEISMIK DAN PEMBAHASANNYA}

\subsection{Akurasi FMM}

Akurasi FMM pertama-tama dicek untuk model bumi dengan distribusi kecepatan homogen, atau dalam hal ini $F=1$. Sehingga, waktu tempuh menuju suatu titik sama dengan jarak dari sumber ke titik tersebut. Gambar 6a menunjukkan perbandingan kontur dari hasil analitik (jarak antara suatu titik terhadap titik asal) dengan yang dihasilkan FMM orde satu serta orde dua untuk ukuran grid 2D (101 X 101). Terlihat bahwa FMM orde 2 memberikan hasil yang lebih mendekati hasil analitik. Hal ini tentu saja mengkonfirmasi bahwa akurasi akan lebih baik seiring membersarnya orde FMM. Gambar 6b, 6c dan 6d memperlihatkan kontur distribusi jarak untuk kasus FMM orde satu , kasus analitik, dan kasus FMM orde dua secara berurutan.

Akurasi skema-skema FMM 2D untuk berbagai ukuran grid pada kasus homogen diperlihatkan pada Tabel 1. Semakin banyak ukuran grid dan semakin besar orde FMM maka akurasi akan bertambah atau nilai RMS error akan mengecil. Perbedaan nilai error ini untuk orde satu dan orde dua adalah sekitar satu orde magnitude (10 kali lipat). Tabel 2 menunjukkan akurasi FMM pada kasus 3D untuk orde satu dan orde dua untuk ukuran grid yang berbedabeda. Kesimpulan yang sama seperti dari Analisa akurasi FMM pada Tabel 1 yaitu semakin banyak ukuran grid dan semakin besar orde FMM maka akurasi semakin baik.

Gambar 7a-7d menunjukkan nilai error terhadap posisi sel untuk skema FMM orde satu dan orde dua untuk kasus 2D maupun 3D. Osilasi nilai error pada semua skema menunjukkan bahwa semakin banyak ukuran grid dan semakin jauh dari sumber, maka akurasi perhitungan pun semakin
Tabel 1. Akurasi FMM pada model kecepatan homogen 2D

\begin{tabular}{lcr}
\hline Grid & RMS Error Orde 1 & RMS Error Orde 2 \\
\hline $21^{2}$ & $3,09 \%$ & $0,50 \%$ \\
$51^{2}$ & $1,97 \%$ & $0,29 \%$ \\
$101^{2}$ & $1,30 \%$ & $0,17 \%$ \\
$151^{2}$ & $1,00 \%$ & $0,13 \%$ \\
\hline
\end{tabular}

Tabel 2. Akurasi FMM pada model kecepatan homogen 3D

\begin{tabular}{lcc}
\hline Grid & RMS Error Orde 1 & RMS Error Orde 2 \\
\hline $11^{3}$ & $6,09 \%$ & $0,61 \%$ \\
$21^{2}$ & $4,60 \%$ & $0,37 \%$ \\
$31^{2}$ & $3,70 \%$ & $0,27 \%$ \\
\hline
\end{tabular}
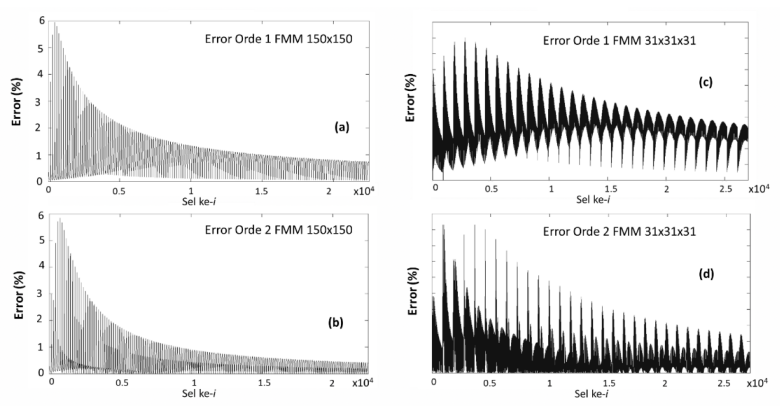

Gambar 7. (a) Grafik error sel ke-i pada FMM orde satu dengan ukuran grid $151^{2}$; (b) error pada FMM orde dua dengan ukuran grid $151^{2}$; (c) error pada FMM orde 1 dengan ukuran grid $31^{3}$; (d) error pada FMM orde 2 dengan ukuran grid $31^{3}$

meningkat. Untuk kasus 2D, FMM orde satu memberikan error maksimum 5,94\% dan orde $21,17 \%$. Sedangkan untuk kasus 3D, FMM orde satu memberikan error maksimum $9,01 \%$ dan orde $21,86 \%$.

\subsection{Hasil Simulasi FMM}

\subsubsection{Pembiasan dan Pemantulan}

Gambar 8a memperlihatkan distribusi waktu tempuh gelombang bias untuk model Bumi dua lapis. Lapisan pertama memiliki kecepatan $2500 \mathrm{~m} / \mathrm{s}$ dan lapisan kedua memiliki kecepatan $7500 \mathrm{~m} / \mathrm{s}$. Defleksi lingkaran-lingkaran waktu tempuh terlihat pada bidang batas antar lapisan dan distribusi waktu tempuh yang lebih kecil (lebih cepat) mendominasi pada lapisan bawah. Pembiasan yang dihasilkan sesuai dengan teori di mana jika diambil sudut sudut datang $\theta_{i}=19,0^{\circ}$ terhadap normal, maka akan dihasilkan sudut bias $\theta_{r}=77,6^{\circ}$ seperti yang diperlihatkan pada Gambar $8 \mathrm{~b}$.

Pemantulan yang dihasilkan oleh skema FMM ini telah sesuai dengan teori di mana sudut pantul sama dengan sudut dating seperti dicontohkan pada Gambar 8c. Hasilhasil yang diperlihatkan pada Gambar 6, 7 dan 8 serta Tabel 1 dan 2 cukup memberikan keyakinan bahwa skema pemodelan ke-depan perambatan gelombang seismik dengan menggunakan FMM valid dan dapat diterima. 


\subsubsection{Aplikasi FMM Pada Model Kecepatan 2D}

\section{Bumi Berlapis}

Untuk menerapkan FMM dalam seismologi, maka perlu digunakan model-model yang berkaitan dengan struktur bawah permukaan Bumi. Salah satu model sederhana yang dapat digunakan adalah model Bumi berlapis dengan kecepatan lapisan paling atas $2500 \mathrm{~m} / \mathrm{s}$ dan kecepatan lapisan paling bawah $5173 \mathrm{~m} / \mathrm{s}$ (Gambar 9a) .

Struktur ini memiliki 3 lapisan yang cukup besar pada kedalaman 0-30 m, 30-70 m, dan 70-100 m. Gambar 9b menunjukkan distribusi waktu tempuh dari model dengan lokasi titik sumber $(0,0)$. Dengan menyimpan detektor pada permukaan dengan posisi $\mathrm{x}=50,75$ dan $100 \mathrm{~m}$, maka didapat lintasan dari sumber ke detektor seperti yang diperlihatkan pada Gambar 9c.

Pada kenyataannya model bumi berlapis tidaklah ideal seperti pada Gambar 9a. Seringkali distribusi kecepatan pada suatu lapisan mengandung nilai ketidakpastian yang dalam hal ini direpresentasikan dengan gangguan atau noise nilai kecepatan. Gangguan diberikan secara acak dengan nilai antara $10 \%$ pada bagian paling atas hingga $5 \%$ pada bagian paling bawah. Sama dengan kasus sebelumnya, sumber terletak di titik $(0,0)$. Meski kecenderungan umum tidak berubah, namun detail-detail distribusi waktu tempuh memperlihatkan perbedaan yang dapat dikenali antara kasus tanpa gangguan (Gambar 9b) dengan kasus terdapat gangguan (Gambar 9e).

Keberadaan gangguan merubah kelengkungan lintasan meskipun tidak signifikan, termasuk merubah lokasi-lokasi titik pantul yaitu di $\mathrm{x}=25,37,5$ dan $50 \mathrm{~m}$ pada kasus tanpa gangguan (Gambar 9c) menjadi $\mathrm{x}=27,39$ dan $48 \mathrm{~m}$ pada kasus dengan gangguan (Gambar 9f) untuk lokasi-lokasi detektor yang sama.

\section{Bumi Berlapis dengan Rongga Kecepatan}

Kemungkinan keberadaan rongga udara atau gua atau aliran fluida di bawah permukaan Bumi juga dimodelkan dengan struktur berlapis dengan sisipan rongga berkecepatan $340 \mathrm{~m} / \mathrm{s}$ seperti diperlihatkan pada Gambar 10a.

Pada kasus model kecepatan berlapis dengan rongga, apabila sumber berada pada $(0,0)$, maka dihasilkan distribusi waktu tempuh seperti yang diperlihatkan Gambar 10b. Konsentrasi waktu tempuh yang besar (lambat) tentu saja akan berada pada rongga dan terlihat nilai distribusi waktu tempuh di belakang rongga akan membesar (dilihat dari kelurusan sumber-rongga) dibandingkan dengan kasus jika tak terdapat rongga.

Hal seperti ini merupakan panduan penting untuk memahami perilaku distribusi waktu tempuh apabila terdapat struktur-struktur penghalang seperti rongga dengan nilai kontras kecepatan yang ekstrim. Sama dengan kasuskasus sebelumnya, detektor terletak di permukaan pada posisi $\mathrm{x}=50,75$ dan $100 \mathrm{~m}$ dan lintasan gelombang seismik pantul diperlihatkan pada Gambar 10c. Sesuai dengan yang diprediksi dari teori, gelombang cenderung bergerak melewati medium dengan kecepatan yang lebih tinggi dan menghindari rongga udara di tengah model. Detektor di permukaan pada posisi $\mathrm{x}=75 \mathrm{~m}$ akan merekan waktu tempuh dengan lintasan yang lebih panjang seperti diperlihatkan pada Gambar 10c. Terlihat juga dalam contoh kasus ini,

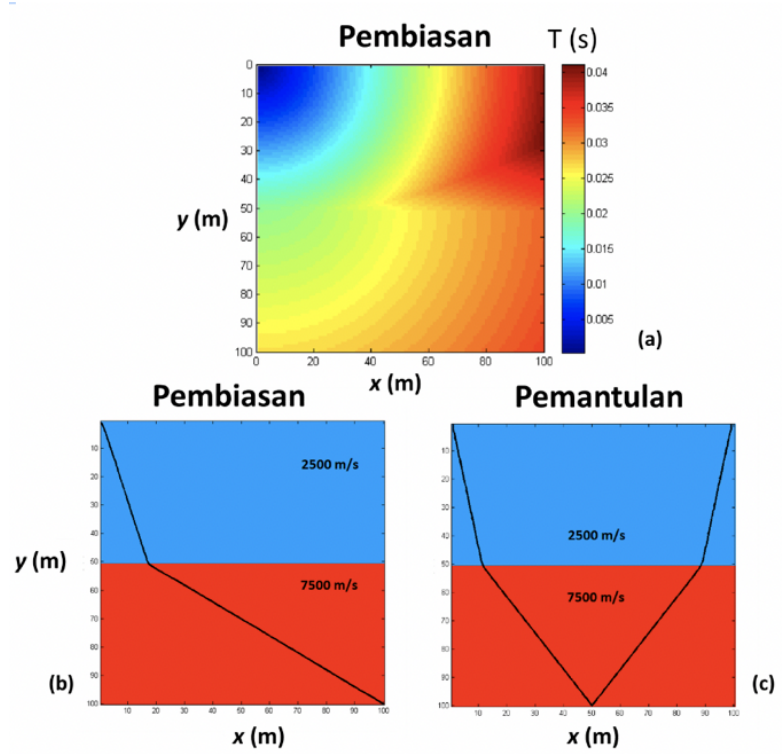

Gambar 8. (a) Waktu tempuh gelombang bias untuk kasus model dua lapis. Lapis pertama memiliki kecepatan $2500 \mathrm{~m} / \mathrm{s}$ dan lapis kedua $7500 \mathrm{~m} / \mathrm{s}$. (b) Contoh lintasan gelombang bias dan (c) contoh lintasan gelombang pantul.
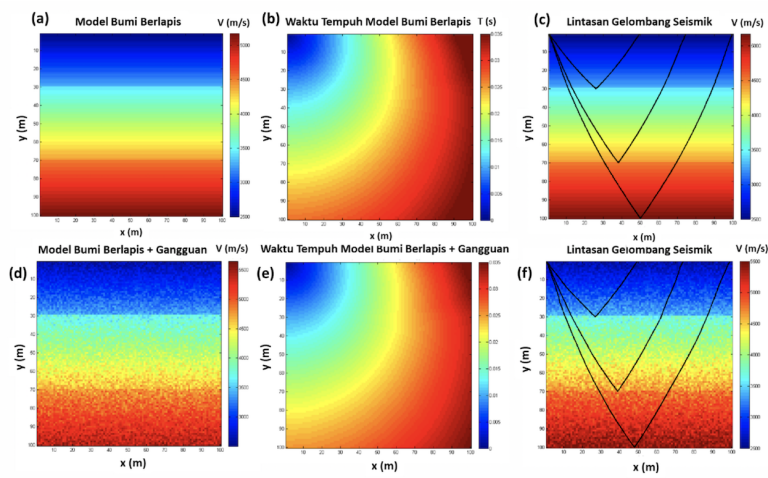

Gambar 9. (a) Model kecepatan untuk Bumi berlapis. (b) Waktu tempuh Bumi berlapis. (c) Lintasan gelombang pada Bumi berlapis. (d), (e) dan (f) masing-masing sama dengan (a), (b) dan (c) dengan model kecepatan pada tiap lapisan diberi gangguan (noise).
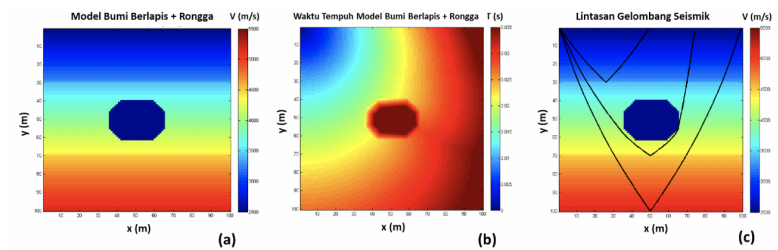

Gambar 10. (a) Model Kecepatan Bumi berlapis dengan rongga. (b) Waktu tempuh untuk model berrongga. (c) Lintasan gelombang pada Bumi berlapis dengan rongga. 

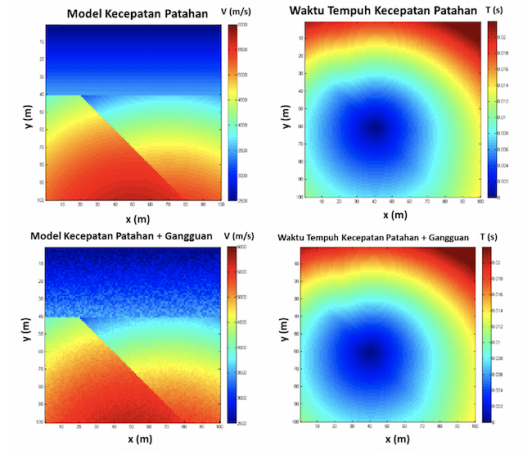

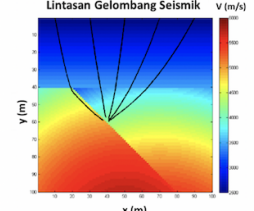

$x|m|$

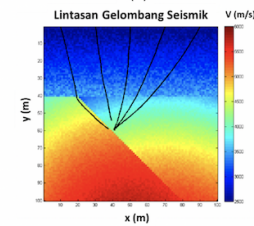

Gambar 11. (a) Distribusi kecepatan untuk model patahan dengan sumber berada pada titik $(40,60)$. (b) Waktu tempuh model kecepatan patahan. (c) Lintasan gelombang seismik untuk detektor yang berada di permukaan pada $\mathrm{x}=10$, 30, 50, 70 dan $90 \mathrm{~m}$. (d) Model kecepatan yang sama dengan (a) namun diberi gangguan (noise). (e) Waktu temputh model kecepatan dengan gangguan. (f) Lintasan gelombang seismik untuk model kccepatan yang diberi gangguan.

titik pantul lintasannya bergeser ke kanan yaitu ke titik $\mathrm{x}$ $=50 \mathrm{~m}$ dibanding dengan kasus tanpa rongga (lihat Gambar $9 c)$.

\section{Model Patahan}

Salah satu struktur yang secara dominan menyebabkan gempa bumi adalah patahan. Gambar 11a menunjukkan struktur bawah permukaan yang memiliki patahan dengan distribusi kecepatan yang lebih kompleks dari model-model sebelumnya. Sumber dimodelkan berada pada titik $(40,60)$. Distribusi waktu tempuh terkait diperlihatkan pada Gambar 11b yang mengindikasikan keberadaan patahan sebagai diskontinuitas waktu tempuh. Detektor dipasang di permukaan pada posisi $\mathrm{x}=10,30,50,70$ dan 90m dan lintasan gelombang yang bersesuaian diperlihatkan pada Gambar 11c.

Gambar 11d, 11e dan 11f adalah hasil-hasil yang sama dengan Gambar 11a, 11b dan 11c namun untuk model kecepatan yang diberi gangguan Pada kasus ini ditambahkan nilai acak dengan rata-rata $300 \mathrm{~m} / \mathrm{s}$ dari 0-40 m dan $100 \mathrm{~m} / \mathrm{s}$ dari $40-100 \mathrm{~m}$ setara dengan gangguan maximum $12 \%$ dan minimum $5 \%$. Secara umum waktu tempuh memperlihatkan karakteristik yang sama dengan yang tak diberi gangguan, begitu pun lintasan gelombang seismiknya, namun detail kelengkungan lintasan terlihat berbeda yaitu sedikit lebih kasar.

\subsubsection{Aplikasi FMM Pada Model Kecepatan 3D}

Skema FMM berhasil diterapka pula pada kasus 3D dengan model kecepatan yang sama dengan model kecepatan 2D. Model kecepatan Bumi berlapis 3D diperlihatkan pada Gambar 12a. Untuk sumber yang terletak pada sumber pada $(0,0,0)$ distribusi waktu tempuhnya diperlihatkan pada Gambar 12b. Sebagai contoh, posisi detektor ada di permukaan yaitu pada posisi $(50,0,50),(0,50,-50),(0,50$, $-100),(50,50,0),(50,50,-50),(50,50,-100),(100,50,0)$,
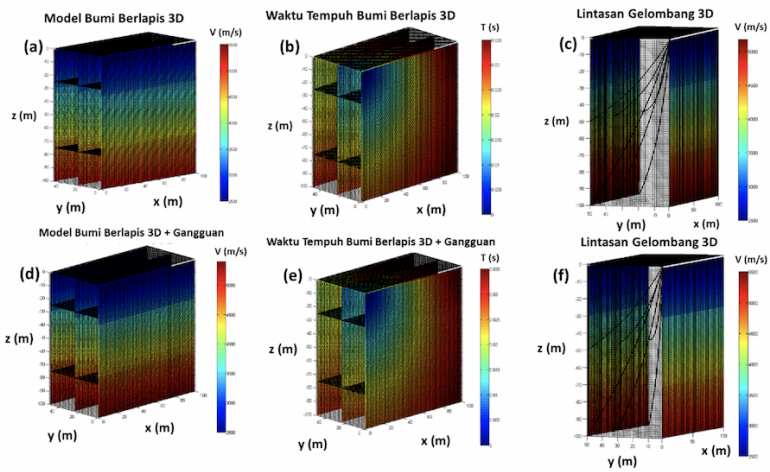

Gambar 12. (a) Model kecepatan Bumi berlapis 3D. (b) Waktu tempuh Bumi berlapis 3D. (c) Lintasan gelombang sesimik. (d) Model kecepatan Bumi berlapis 3D dengan gangguan. (e) Waktu tempuh Bumi berlapis 3D dengan gangguan. (f) Lintasan gelombang Bumi berlapis 3D yang diberi gangguan.
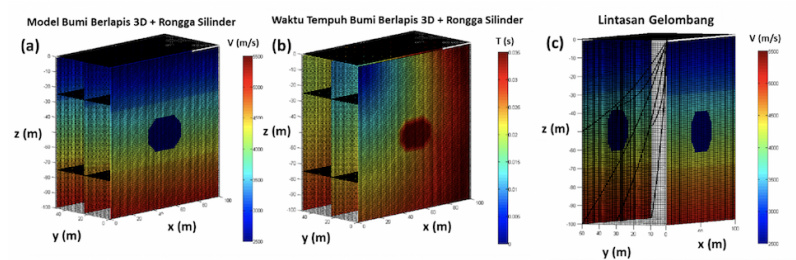

Gambar 13. (a) Model kecepatan Bumi berlapis 3D dengan sisipan rongga. (b) Waktu tempuh Bumi berlapis 3D dengan rongga. (c) Lintasan gelombang seismik dalam ruang 3D

$(100,50,-50)$ dan $(100,50,-100)$, maka lintasan gelombang yang menembus ruang 3D diperlihatkan pada Gambar 12c.

Gambar 12d, 12e dan 12f adalah hasil pemodelan FMM 3D untuk model Bumi berlapis yang diberi gangguan yang secara berurutan memperlihatkan bahwa dalam rentang gangguan yang diberikan, fitur-fitur umum waktu tempuh dan lintasan gelombang tidak berubah secara signifikan.

Kasus model kecepatan Bumi berlapis yang disisipi rongga secara 3D yang lokas titik sumber dan detektornya sama dengan kasus bumi berlapis tanpa rongga diperlihatkan pada Gambar 13a sedangkan distribusi waktu tempuh dan lintasa gelombangnya diperlihatkan pada gambar 13b dan 13c. terlihat bahwa lintasan sedemikian menghindari konsentrasi kecepatan rongga di dalam ruang 3D.

Untuk kasus patahan 3D dengan sumber terletak pada titik $(40,25,60)$ (Gambar 14a) dan detektor pada $(0,0,0)$, $(0,25,0),(0,50,0),(50,0,0),(50,25,0),(50,50,0),(100,0$, $0),(100,25,0)$ dan $(100,50,0)$, waktu tempuh dan lintasan gelombang dalam ruang 3D diperlihatkan pada gambar $14 \mathrm{~b}$ dan 14c. Padanan hasil pemodelan yang sama namun dengan model kecepatan yang diberi gangguan diperlihatkan pada Gambar 14d, 14e dan 14f.

\subsection{Penentuan Sumber Gelombang Seismik}

Seperti yang telah dibahas pada sub-bab 4.4 .2 untuk kasus yang sederhana seperti yang dibahas pada makalah ini, yaitu struktur kecepatan bukan dianggap sebagai parameter model yang dicari pada tahap inversi melainkan sesuatu 


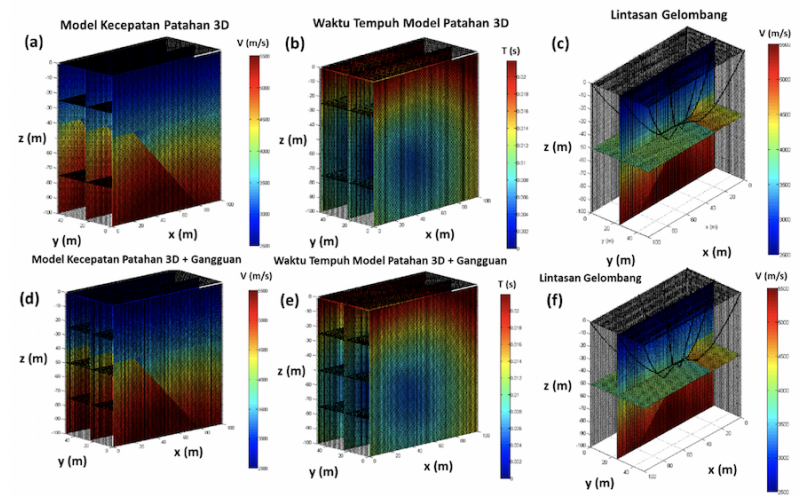

Gambar 14. (a) Distribusi kecepatan untuk model patahan 3D dengan sumber berada pada titik $(40,25,60)$. (b) Waktu tempuh model kecepatan patahan 3D. (c) Lintasan gelombang seismik untuk detektor yang berada di $(0,0,0),(0,25,0),(0,50$, $0),(50,0,0),(50,25,0),(50,50,0),(100,0,0),(100,25,0)$, dan $(100,50,0)$. (d) Model kecepatan yang sama dengan (a) namun diberi gangguan (noise). (e) Waktu temputh model kecepatan dengan gangguan. (f) Lintasan gelombang seismik untuk model kccepatan yang diberi gangguan.
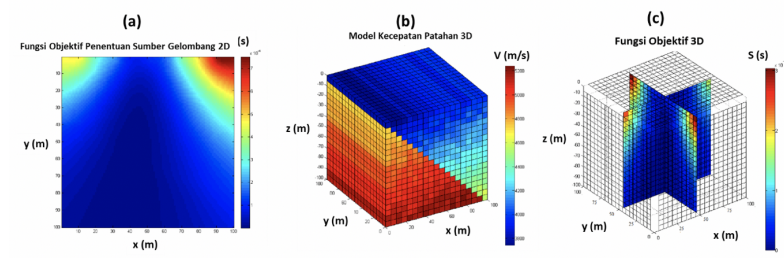

Gambar 15. (a) Fungsi objektif untuk menentukan sumber gelombang kasus 2D. (b) Model kecepatan patahan 3D dengan ukuran grid $21 \times 21 \times 21$. (c) Fungsi objektif untuk menentukan sumber gelombang pada kasus 3D.

yang dianggap tetap (diberikan nilainya), maka persoalan sumber gelombang seismik ditentukan dengan mudah dari konsep fungsi objektif yang telah dihitung. Misalkan untuk kasus 2D di mana struktur kecepatannya seperti pada Gambar 11a dan sumber terletak pada titik $(40,60)$ dan waktu awal kejadian adalah 09:00. Maka ternyata dengan memanfaatkan Persamaan (58) akan didapat distribusi nilai fungsi obyektif seperti yang diperlihatkan pada Gambar 15a. Nilai minimum dari fungsi objektif di atas terletak pada sel $(41,61)$ yang merupakan salah satu sel terdekat dari titik $(40,60)$. Waktu awal yang didapatkan pun mendekati 9:00 dengan perbedaan $\mathrm{O}\left(10^{-3}\right)$.

Pada kasus 3D digunakan model seperti pada Gambar $15 \mathrm{~b}$ dengan ukuran grid $21 \times 21 \times 21$. Sumber terletak di titik $(50,50,50)$ dan waktu 09:00. Nilai minimum dari fungsi objektif di atas terletak pada sel $(10,10,10)$ yang merupakan salah satu sel terdekat dari titik $(50,50,50)$ seperti terlihat pada Gambar 15c. Waktu awal yang didapatkan pun mendekati 9:00 dengan perbedaan $\mathrm{O}\left(10^{-3}\right)$.

\section{KESIMPULAN}

Dalam ruang lingkup studi ini, Fast Marching Method telah berhasil diaplikasikan pada berbagai model kecepatan bawah permukaan. FMM bekerja dengan $\mathrm{O}(N \log N)$ langkah, $\mathrm{N}$ merupakan jumlah titik, dengan error RMS i $1 \%$ pada skema orde dua. Didapatkan bahwa Fast Marching Method merupakan metode yang akurat, robust, dan efisien untuk digunakan dalam memodelkan penjalaran gelombang pada domain 2D dan 3D. Dari hasil-hasil yang didapat, baik pada kasus 2D maupun 3D terlihat bahwa akurasi maupun aplikabilitas FMM untuk diterapkan dalam skema pemodelan ke-depan penjalaran gelombang seismik yang merupakan bagian penting dalam interpretasi sesungguhya dari data seismik yaitu tahap inversi. Ketersediaan skema pemodelan ke-depan yang valid dari segi prinsip-prinsip fisis dan akurat merupakan salah satu kunci utama keberhasilan skema inversi.

\section{Ucapan Terima Kasih}

Penulis mengucapkan terima kasih yang sebesar-besarnya kepada Laboratorium Pemodelan dan Inversi, KK Fisika Bumi dan Sistem Kompleks, FMIPA Institut Teknologi Bandung atas penggunaan fasilitas komputasi yang sangat mendukung selesainya studi ini.

\section{DAFTAR PUSTAKA}

Dicker, Je., 2006 Fast Marching Methods and Level Set Methods: An Implementation. Kelowna: University Of British Columbia.

LeVeque, R.J., 1992. Numerical Methods for Conservation Laws. Basel: Birkhauser.

Osher, S. dan Sethian, J.A., 1998. Fronts Propagating with CurvatureDependent Speed: Algorithms Based on Hamiltonian-Jacobi Formulations. Journal of Computational Physics, 79, pp. 12-49.

Rawlinson, Nick, 2008. Seismology. Canberra: Australian National University.

Rawlinson, Nick., 2005. The Fast Marching Method: An Eective Tool for Tomographic Imaging and Tracking Multiple Phases in Complex Layered Media. Exploration Geophysics, 36, pp.341-350.

Rawlinson, N and Sambridge, M., 2004. Wavefront evolution in strongly heterogeneous layered media using the fast marching method. Geophys. J. Int. 156, 631-647 doi: 10.1111/j.1365-246X.2004.02153.x

Rawlinson, N and Sambridge, M., 2005. The fast marching method: an effective tool for tomographic imaging and tracking multiple phases in complex layered media. Exploration Geophysics, 36, 341-350

Rouy, E. dan Tourin, A. A, 1992. Viscosity Solutions Approach to Shape-From-Shading. SIAM J. Num. Anal, 29, 3, pp. 867-884.

Sethian, J.A., 1996 A Fast Marching Level Set Method for Monotonically Advancing Fronts. Proc. Nat. Acad. Sci., 93, 4, pp.1591-1595

Sethian, J.A., 2005. Level Set Methods and Fast Marching Methods: Evolving Interfaces in Computational Geometry, Fluid Mechanics, Computer Vision, and Material Sciences. Cambridge: Cambridge University Press.

Sethian, J.A. and Popovici, A.M.,1999. 3-D travel time computation using the fast marching method, Geophysics 64, $516-523$. 
Sod, G.A., 1985 Numerical Methods in Fluid Dynamics.

Cambridge: Cambridge University Press. 